Asian J. Med. Biol. Res. 2015, 1 (1), 74-79

\author{
Asian Journal of \\ Medical and Biological Research \\ ISSN 2411-4472 \\ www.ebupress.com/journal/ajmbr
}

\title{
Article \\ Prevalence of different reproductive disorders of small ruminants in five upazillas of Mymensingh district
}

\author{
Ahammad Sultan ${ }^{1}$, Md. Rashedul Islam ${ }^{2}$, Rakesh Kumer Yadav $^{3}$, Rupaly Akhter ${ }^{3}$ and Jalal Uddin Ahmed ${ }^{1}$ \\ ${ }^{1}$ Department of Surgery and Obstetrics, Faculty of Veterinary Science, Bangladesh Agricultural University, \\ Mymensingh-2202, Bangladesh \\ ${ }^{2}$ Department of Surgery and Theriogenology, Faculty of Animal Science and Veterinary Medicine, Sher-e- \\ Bangla Agricultural University, Dhaka-1207, Bangladesh \\ ${ }^{3}$ Department of Pharmacology, Faculty of Veterinary Science, Bangladesh Agricultural University, \\ Mymensingh-2202, Bangladesh
}

*Corresponding author: Md. Rashedul Islam, Department of Surgery and Theriogenology, Faculty of Animal Science and Veterinary Medicine, Sher-e-Bangla Agricultural University, Dhaka-1207, Bangladesh. E-mail: rashed.stj036@yahoo.com

Received: 18 May 2015/Accepted: 15 June 2015/ Published: 30 June 2015

Abstract: Small ruminants (goat and sheep) are economically important and promising animal resource in
Bangladesh. Reproductive disorders of goat and sheep cause the great economic problems. Therefore, the aim
of the study was to investigate the prevalence of reproductive disorders in goat and sheep in five upazillas of
Mymensingh district. Records of reproductive disorders were collected from official stock book of different
Upazillas veterinary hospitals of Mymensingh district during April 2010 to March 2011 . Seasonal occurrences
of reproductive disorders were also recorded. Descriptive statistical analysis was done to study the prevalence
of different reproductive disorders of goat and sheep in five upazillas of Mymensingh district. Out of 4804
clinical cases, a total of 147 reproductive disorders of goat and sheep were screened out from datasheet of
official stock book. Among the five upazila, the prevalence of reproductive disorders was higher in Muktagacha
$(3.35 \%)$ and lower in Fulbaria (2.38\%). Prevalence of reproductive disorders in all upazila was higher in sheep
$(4.12 \%)$ than goat $(2.88 \%)$. Prevalence of reproductive disorders of goat was higher in Tarakanda (3.26\%) and
lower in Fulbaria $(2.03 \%)$ and the prevalence of reproductive disorders of sheep was higher in Gaforgaon
$(5.22 \%)$ and lower in Haluaghat $(3.15 \%)$. The major reproductive disorders recorded in goats were dystocia
$(41.2 \%)$, abortion $(21.8 \%)$, mastitis $(21.8 \%)$, retained placenta (11.8\%) and pyometra (3.4\%). Similarly, major
reproductive disorders in sheep were dystocia (53.7\%), abortion (25\%), pyometra (7.1\%), mastitis (7.1\%) and
retained placenta (7.1\%). Moreover, seasonal prevalence of reproductive disorders was higher in summer than
winter in the species, goat (57.14\%) and sheep (12.25\%). It was concluded that the most pressing constraint on
goat and sheep reproduction in Bangladesh is dystocia, abortion and mastitis. Strategies should be taken to
minimize their occurrence.

Keywords: small ruminants; reproductive disorders; prevalence; seasonal

\section{Introduction}

Livestock is the most prospective sector which addresses the problems of landless, marginal and small-scale farmers and capable of helping in poverty alleviation. This sector contributes about $2.7 \%$ of national Gross Domestic Product (GDP) in Bangladesh (Economic Review, 2010). The contribution of livestock sub-sector is $13 \%$ earning of total foreign currency in Bangladesh (Alam, 1993). In the livestock sector, small ruminants especially goat and sheep are very important in rural economy and nutrition. Goat is numerically and 
economically important and promising animal resources in the developing countries especially in Asia and Africa (Hussain, 1999). At present, there are 56.7 million goats and 1.6 million sheep represents in Bangladesh (FAOSTAT, 2008). The total numbers of goats and sheep were 738 and 201 thousand, respectively in Mymensingh district (DLS, 2010). Goats rank first position in terms of total livestock population in Bangladesh (FAO, 1999). The importance of goat and sheep is strongly emphasized for their versatile production profile and valuable contribution like meat, milk, industrial raw product such as skin, fiber and manure.

Reproductive disorders of goat and sheep are the great economic problems. The reproductive disorders are the major causes of reduced fertility in goat and sheep. Reproductive abnormalities have been described as the largest single cause of loss of livestock production (McDowell, 1972). It has negative effect on meat production since pregnancy and parturition are prerequisite for reproduction. Reproduction of goats has an impact on successful fertility (Sattar and Khan, 1988). Gynaeco-obstetrical disorders like dystocia, abortion, retention of placenta and other miscellaneous abnormalities like metritis, pyometra, vaginitis are the important factors causing economical loss to goat and sheep industry.

The differences in management and production systems and environmental conditions under which goats and sheep are maintained could greatly affect the occurrence of reproductive health problems. Although, major reproductive disorders greatly responsible for high economic loss in dairy goat and sheep, limited research have been done on the prevalence and current treatment practices of the reproductive disease in Mymensingh district. But no significant systemic studies have been done on reproductive disorders of goat and sheep in Mymensingh district. Therefore, the study was designed to investigate the magnitude of major reproductive disorders in goat and sheep in Mymensingh districts.

\section{Materials and Methods}

\subsection{Study area and Animal}

It was decided at the outset that the investigation should cover all the 12 upazillas of Mymensingh district but due to some practical problems and logistics in conducting investigation 5 of the 12 upazillas were selected. The total number of sheep and goat population in 5 upazillas (Table-1) and in reciprocal, another 7 upazillas (Table-2) data was collected. So the study was conducted in five upazillas under the district of Mymensingh, located at the north side and $124 \mathrm{kms}$ away from Dhaka city. This area consists of low, flat and fertile land except the hilly regions in northeast and southeast. The mean annual temperature is about $26^{\circ} \mathrm{C}$ with an extreme range between $40-43^{\circ} \mathrm{C}$. The averages annual rainfall varies from $1429-4338 \mathrm{~mm}$. All the sick animals brought for treatment to the upazillas veterinary hospital were first registered in the official stock book. The description of each registered animal and owner's complaint were recorded. Out of total clinical cases of goat and sheep only reproductive disorders were included in present study.

\subsection{Data collection}

The investigator personally visited all the selected upazillas, extracted the information on reproductive disorders from the data sheet designed by the hospital authority. Therefore, records of clinical cases were collected during April 2010 to March 2011 from official stock book of five Upazillas veterinary hospitals out of 12 upazillas of Mymensingh district viz: Fulbaria, Gaforgoan, Haluaghat, Muktagacha and Tarakanda. Out of 4804 clinical cases of goat and sheep, only 147 reproductive disorders were screened out from the datasheet of official stock book that was used by the hospital authority. The information on the occurrence of disorders related to season of year were also recorded. The following datasheet was used by the hospital authority for keeping record of clinical cases (Annex 1).

\subsection{Data analysis}

Descriptive statistics was done to study the prevalence of reproductive disorders among total clinical cases of goat and sheep in veterinary hospitals of Mymensingh districts. T-test and chi-square test were perfomed to get the significant value by using SPSS package.

\section{Results}

A total 147 clinical reproductive cases recorded from different veterinary hospitals in five upazillas of Mymensingh district. Occurrences of reproductive disorders in five upazillas are shown in Table 3. Considering the study area the overall prevalence of reproductive disorders was $3.1 \%$. Among the five upazillas, the prevalence of reproductive disorders was higher in Muktagacha (3.4\%) and lower in Fulbaria (2.4\%) followed 
by $3.3 \%, 3.3 \%$ and $3.1 \%$ in Gaforgaon, Tarakanda and Haluaghat, respectively. There was no significant difference the prevalence of reproductive disorders $(\mathrm{P}>0.05)$ among the five upazillas (Table 3). Prevalence of reproductive disorders of different upazillas is presented in Table 4 . The prevalence of reproductive disorders was higher in sheep $(4.1 \%)$ than goat $(2.9 \%)$. In goat among five upazillas, the prevalence of reproductive disorders was higher in Tarakanda (3.3\%) and lower in Fulbaria $(2.0 \%)$ followed by Muktagacha (3.2\%), Haluaghat $(3.1 \%)$ and Gaforgaon (2.9\%). In sheep the prevalence of reproductive disorders was higher in Gaforgaon (5.2\%) and lower in Haluaghat (3.2\%) followed by Fulbaria (4.5\%), Muktagacha (4.4\%) and Tarakanda (3.4\%). There was no significant difference in the prevalence of reproductive disorders of goat and sheep $(\mathrm{P}>0.05)$ among the five upazillas (Table 4).

In goat, a total of 119 reproductive disorders were recorded. The overall major clinical conditions observed in goats were higher in dystocia $(41.2 \%)$, followed by abortion (21.8\%), mastitis (21.8\%), retained placenta $(11.8 \%)$ and lower in pyometra (3.4\%). There was no significant difference the prevalence of reproductive disorders of goat $(\mathrm{P}>0.05)$ among the five upazillas (Table 5). In sheep, a total of 28 reproductive disorders were recorded. Among them the highest percentage was dystocia (53.7\%), followed by abortion (25\%), pyometra $(7.1 \%)$, mastitis $(7.1 \%)$ and retained placenta $(7.1 \%)$. There was no significant the prevalence of difference reproductive disorders of goat $(\mathrm{P}>0.05)$ among the five upazillas (Table 6). Considering the species, prevalence of dystocia $(53.7 \%)$, abortion $(25 \%)$ and pyometra $(25 \%)$ was higher in sheep than goat. However prevalence of retained placenta $(11.8 \%)$ and mastitis $(21.8 \%)$ was higher in goat than sheep. In goat, among different reproductive disorders, the prevalence was higher in dystocia (41.2\%) and lower in pyometra (3.4\%). Prevalence of reproductive disorders, dystocia (53.7\%) was higher and pyometra (7.1\%), mastitis $(7.1 \%)$ and pyometra $(7.1 \%)$ were lower in cases of sheep.

Reproductive disorders of sheep and goat observed during two seasons in Mymensingh district are summarized in Table 7. Over all seasonal prevalence of reproductive disorders was higher in summer than winter in the species goat $(57.1 \%)$ and sheep (12.3\%). Among the different reproductive disorders, prevalence of dystocia was higher in goat $(21.8 \%)$ and sheep (6.1\%). The prevalence of reproductive disorders of goat were 14.3, 12.3, 6.8 and $2.0 \%$ in mastitis, abortion, retained placenta and pyometra, respectively in summer season. However, in winter 5.4, 3.4, 2.7 and $0.7 \%$ were abortion, mastitis retained placenta and pyometra, respectively. The prevalence of reproductive disorders of sheep were observed $2.7,1.4,1.4$ and $0.7 \%$ were abortion, mastitis, pyometra, and retained placenta, respectively in summer season. However, in winter 4.0, 2.0 and $0.7 \%$ dystocia, abortion and retained placenta, respectively. There was no significant difference the prevalence of reproductive disorders $(\mathrm{P}>0.05)$ between summer and winter season among the five upazillas with both species.

Table 1. Goat and sheep population in selected five Upazillas in Mymensingh district.

\begin{tabular}{lllll}
\hline Serial No. & Upazila & \multicolumn{2}{c}{ Number of goat and sheep } & Total \\
\cline { 3 - 5 } & & Goats & Sheep & 76720 \\
$\mathbf{0 1}$ & Fulbaria & 75925 & 795 & 37600 \\
$\mathbf{0 2}$ & Muktagacha & 35380 & 2220 & 87840 \\
$\mathbf{0 3}$ & Tarakanda & 85100 & 2740 & 65862 \\
$\mathbf{0 4}$ & Gaforgaon & 65210 & 652 & 45608 \\
$\mathbf{0 5}$ & Haluaghat & 45200 & 408 & 313630 \\
\hline Total & & 306815 & 6815 & \\
\hline
\end{tabular}

Table 2. Goat and sheep population excluded in seven Upazillas in Mymensingh district.

\begin{tabular}{|c|c|c|c|c|}
\hline \multirow[t]{2}{*}{ Serial No. } & \multirow[t]{2}{*}{ Upazila } & \multicolumn{2}{|c|}{ Number of goat and sheep } & \multirow[t]{2}{*}{ Total } \\
\hline & & Goats & Sheep & \\
\hline 01 & Sadar & 95120 & 3950 & 99070 \\
\hline 02 & Trisal & 50812 & 4425 & 55237 \\
\hline 03 & Nandail & 62305 & 260 & 62565 \\
\hline 04 & Iswargonj & 66700 & 3436 & 70136 \\
\hline 05 & Gouripur & 57500 & 232 & 57732 \\
\hline 06 & Vhaluka & 63930 & 872 & 64802 \\
\hline 07 & Dhobaura & 35728 & 110 & 35838 \\
\hline Total & & 432095 & 13285 & 445380 \\
\hline
\end{tabular}

Source: DLS-report 2010 in Mymensingh. 
Table 3. Overall prevalence of reproductive disorders among total clinical cases in five upazillas in Mymensingh.

\begin{tabular}{lllll}
\hline Serial No. & Upazilla & Clinical cases & $\begin{array}{l}\text { Reproductive } \\
\text { disorders }\end{array}$ & Percentage (\%) \\
\hline 01 & Fulbaria & 1093 & 26 & 2.4 \\
02 & Gaforgaon & 1008 & 33 & 3.3 \\
03 & Haluaghat & 706 & 22 & 3.1 \\
04 & Muktagacha & 805 & 27 & 3.4 \\
05 & Tarakanda & 1192 & 39 & 3.3 \\
Total & & 4804 & 147 & 3.1 \\
P value & 0.998 & \multicolumn{2}{l}{ Non Significant $(\mathrm{P}>0.05)$} \\
\hline \multicolumn{2}{l}{ Significant level } & &
\end{tabular}

Table 4. Prevalence of reproductive disorders in goat and sheep among total clinical cases during a year.

\begin{tabular}{lllllll}
\hline Upazila & $\begin{array}{l}\text { Clinical } \\
\text { cases }\end{array}$ & $\begin{array}{l}\text { Goat } \\
\text { Reproductive } \\
\text { disorders }\end{array}$ & \% & $\begin{array}{l}\text { Sheep } \\
\text { Clinical } \\
\text { cases }\end{array}$ & $\begin{array}{l}\text { Reproductive } \\
\text { disorders }\end{array}$ & \% \\
\hline Fulbaria & 937 & 19 & 2.0 & 156 & 7 & 4.5 \\
Gaforgaon & 874 & 26 & 2.9 & 134 & 7 & 5.2 \\
Haluaghat & 579 & 18 & 3.1 & 127 & 4 & 3.2 \\
Muktagacha & 692 & 22 & 3.2 & 113 & 5 & 4.4 \\
Tarakanda & 1043 & 34 & 3.3 & 149 & 5 & 3.4 \\
Total & 4125 & 119 & 2.9 & 679 & 28 & 4.1 \\
P value & & \multicolumn{3}{c}{0.075} \\
\hline Significant level & & \multicolumn{3}{c}{ Son Significant $(\mathrm{P}>0.05)$} \\
\hline
\end{tabular}

Table 5. Reproductive disorders of goats in Mymensingh district.

\begin{tabular}{lllllll}
\hline Upazila & Dystocia & Abortion & Mastitis & Pyometra & $\begin{array}{l}\text { Retained } \\
\text { placenta }\end{array}$ & Total \\
\hline Fulbaria & 8 & 5 & 4 & 0 & 2 & 19 \\
Gaforgaon & 10 & 4 & 7 & 2 & 3 & 26 \\
Haluaghat & 5 & 6 & 4 & 1 & 2 & 18 \\
Muktagacha & 9 & 5 & 3 & 1 & 4 & 22 \\
Tarakanda & 17 & 6 & 8 & 0 & 3 & 34 \\
Total & 49 & 26 & 26 & 4 & 14 & 119 \\
& $(41.2 \%)$ & $(21.8 \%)$ & $(21.8 \%)$ & $(3.4 \%)$ & $(11.8 \%)$ & $(100 \%)$ \\
P value & 0.850 & & & \\
\hline Significant level & \multicolumn{7}{l}{ Non Significant $(\mathrm{P}>0.05)$} & & & \\
\hline
\end{tabular}

Table 6. Reproductive disorders of sheep in Mymensingh district.

\begin{tabular}{lllllll}
\hline Upazila & Dystocia & Abortion & Mastitis & Pyometra & $\begin{array}{l}\text { Retained } \\
\text { placenta }\end{array}$ & Total \\
\hline Fulbaria & 5 & 1 & 0 & 1 & 0 & 7 \\
Gaforgaon & 4 & 3 & 0 & 0 & 0 & 7 \\
Haluaghat & 3 & 1 & 0 & 0 & 0 & 4 \\
Muktagacha & 1 & 1 & 2 & 0 & 1 & 5 \\
Tarakanda & 2 & 1 & 0 & 1 & 1 & 5 \\
Total & 15 & 7 & 2 & 2 & 2 & 28 \\
& $(53.7 \%)$ & $(25 \%)$ & $(7.1 \%)$ & $(7.1 \%)$ & $(7.1 \%)$ & $(100 \%)$ \\
P value & 0.843 & & & & \\
\hline Significant level & \multicolumn{7}{l}{ Non Significant (P>0.05) } \\
\hline
\end{tabular}


Table 7. Reproductive disorders of sheep and goat observed during two seasons in Mymensingh district.

\begin{tabular}{|c|c|c|c|c|c|}
\hline \multirow{2}{*}{ Diseases } & \multicolumn{2}{|c|}{ Goats } & \multicolumn{2}{|c|}{ Sheep } & \multirow[t]{2}{*}{ Total } \\
\hline & Summer & Winter & Summer & Winter & \\
\hline Dystocia & $21.8 \%(32)$ & $11.6 \%(17)$ & $6.1 \%(9)$ & $4.0 \%(6)$ & $43.5 \%(64)$ \\
\hline Abortion & $12.3 \%(18)$ & $5.4 \%(8)$ & $2.7 \%(4)$ & $2.0 \%(3)$ & $22.5 \%(33)$ \\
\hline Mastitis & $14.3 \%(21)$ & $3.4 \%(5)$ & $1.4 \%(2)$ & $0 \%(0)$ & $19.1 \%(28)$ \\
\hline Retained Placenta & $6.8 \%(10)$ & $2.7 \%(4)$ & $0.7 \%(1)$ & $0.7 \%(1)$ & $10.9 \%(16)$ \\
\hline Pyometra & $2.0 \%(3)$ & $0.7 \%(1)$ & $1.4 \%(2)$ & $0 \%(0)$ & $4.1 \%(6)$ \\
\hline Total & $57.1 \%(84)$ & $23.4 \%(35)$ & $12.3 \%(18)$ & $6.8 \%(10)$ & $100 \%(147)$ \\
\hline$P$ value & & 0.852 & & & \\
\hline
\end{tabular}

\section{Discussion}

Considering the study area, overall prevalence of reproductive disorders was $3.1 \%$. Among the five upazillas, the prevalence of reproductive disorders was higher in Muktagacha (3.4\%) and lower in Fulbaria (2.4\%).

The prevalence rate of dystocia was $41 \%$ in goats and $54 \%$ in sheep in the present study, which is higher than that observed by Srivastava et al., (1985) who reported occurance of dystocia 3.2\% in local goat and 1.9\% in Angora. In another study, Majeed and Taha (1989) reported occurrence 52.9\% fetal and $47.1 \%$ maternal dystocia. In a recent study Câmara et al., (2009) have observed higher prevalence of dystocia of sheep occurred in rainy season (about 61.7\%) and reported a major predominance of maternal dystocia $(71.6 \%)$ over fetal dystocia $(29.4 \%)$ with higher prevalence in primiparous. However, dystocia is influenced by factors such as, age and parity as well as breed of the kids.

The prevalence of retained placenta was $12 \%$ in goats and $7 \%$ in sheep in the present study. But this is very lower than that reported in Yankasa sheep (77.3\%) and Red Sokoto goats (95.7\%) (Neils et al., 2009). In comparison, Rahman et al., (1977) and Fthenaki et al., (2000) stated that the prevalence of retained placenta was $(2.2 \%)$ and $(1.5 \%)$ of goat.

Among reproductive disorders the prevalence of pyometra was 3\% in goats and 7\% in sheep in present study. This result is slightly higher than that of Ahmed (1993) who reported $1.4 \%$ occurrence of pyometra in goat an abattoir survey and lower than the finding of Neils et al., (2009) who have observed $100 \%$ and $81.8 \%$ pyometra in Yankasa sheep and Red Sokoto goats. Whereas Karadaş and Timurkaan (2001) have observed the prevalence of pyometra $0.1 \%$ cases of sheep that are lower than the current finding.

The prevalence of abortion was $22 \%$ in goats and $25 \%$ in sheep in this present study. Recently, Ahmed et al., (2008) have reported $35.6 \%$ and $43.7 \%$ incidence of abortion of sheep and goats.

We observed higher prevalence of reproductive disorders in summer than winter in both goat $(57.1 \%)$ and sheep (12.3\%). It may be due to high environmental temperature in summer season which created stress condition on animal. High temperature also favorers the growth of pathogenic bacteria and other microorganisms. As a result, immunity of animal felt down and then pathogenic microorganisms multiply easily.

\section{Conclusions}

It was concluded that the most pressing constraint on goat and sheep reproduction in Bangladesh is dystocia, abortion and mastitis. The reproductive disorders are the major causes of reduced fertility in goat and sheep. Therefore, Gynaeco-obstetrical disorders like dystocia, abortion, retained placenta, vaginitis and other miscellaneous abnormalities like pyometra and metritis are the important factors causing great economical loss to goat and sheep industry. Increased production of goat and sheep meat, skin, goat's milk and sheep wool are deeply related to the management of the reproductive disorders. Therefore strategies should be taken to minimize their occurrence.

\section{Conflict of interest}

None to declare. 


\section{References}

Ahmed JU, 1993. Incidents of gynaeco-obstetrical disorders in Black Bengal goats. Bangladesh Agriculture University Research Progress, 7: 499-505.

Ahmed YF, SM Sokkar, HM Desouky and AH Soror, 2008. Abortion due to Toxoplasmosis in small ruminants. Global Veterinaria, 2: 337-342.

Alam J, 1993. The sector for more investment in Bangladesh. Asian Livestock, 7: 77-78.

Câmara ACL, JAB Afonso, AC Dantas, JA Guimarães, NA Costa, MI Souza and CL Mendonça, 2009. Analysis of factors related to 60 dystocia cases in ewes in the Agreste and semiarid region of Pernambuco, Northeastern Brazil. Cienc. Rural, 39: 2458-2463.

DLS, 2010. An Annual report. Livestock and poultry development activities. Goverment of Bangladesh, Dhaka.

Durrani AZ and N Kamal, 2009. Prevalence of genital tract problems in clinical cases of various species of animals. J. Anim. Plant Sci. 19: 160-162.

FAO (Food and Agricultural Organization of the United Nations), 1999. Production Year Book. Rome, Italy, 53: 213-219.

FAOSTAT, 2008. http://faostat.fao.org/default.aspx.

Fthenaki GC, LS Leontides, GS Amiridis and P Saratsis, 2000. Incidence risk and clinical features of retention of foetal membranes in ewes in 28 flocks in southern Greece. Prev. Vet. Med., 43: 85-90.

Hussain SS, 1999. Sustainable genetic improvment of economic traits of Black Bengal goats through selective and cross breeding. Bangladesh Agricultural University Research Progress, 10: 72-80.

Karadaş E and N Timurkaan, 2001. Pathomorphologic Investigations on the Genital System of Ewes II.Uterus, Cervix and Vagina. Turk. J. Vet. Anim. Sci., 25: 27-37.

Maisi P, 1990. Milk NAGase, CMT and antitrypsin as indicators of caprine subclinical mastitis infections. Small Ruminant Res., 3: 493-501.

Majeed AF and MD Taha, 1989. Dystocia in local goats in Iraq. Small Ruminant Res., 2: 375-301.

McDowell RE, 1972. Improvement of livestock production in warm climates 3rd (Ed.)W.H. Freeman and Company, San Fransisco.

Neils JS, PA Abdu and AKB Sackey, 2009. Some reproductive disorders of the indigenous sheep and goats in Zaria, northern Nigeria. Nigerian Vet. J., 30: 46-50.

Rahman A, A Hossain, MU Ahmed and MM Sen, 1977. Studies on some reproductive performance and biometry of the female genital tract of Black Bengal goat. Indian J. Anim. Sci., 47: 724-725.

Sattar A and MZ Khan, 1988. Incidence and pathology of ovarian diseases of goats. Pakistan Vet. J., 3: 18-21.

Srivastava AK, VK Patil and BK More, 1985. Incidences of various disorders in local, angora crossbreed goats. Indian Vet. J., 62: 935 - 939. 